\title{
TWO NEW ANTS FROM WESTERN NEVADA
}

(Hymenoptera, Formicidae)

MARION R. SMITH

Bureau of Entomology and Plant Quarantine

Agricultural Research Administration

United States Department of Agriculture

Since the ant fauna of Nevada is virtually unknown the two new species described herein are of more than ordinary interest. Both were sent me by Dr. Ira La Rivers of the University of Nevada who collected them in the general region of Pyramid Lake, Washoe County, Nevada. One is a very distinct form of honey ant (Myrmecocystus) which I have named pyramicus because of the pyramidlike structure of the epinotum. The other is a harvesting ant (Veromessor) which, though related to pergandei (Mayr), is definitely different. This new form has been named lariversi in honor of its collector. Illustrations of Myrmecocystus pyramicus are included.

\section{MYRMECOCYSTUS PYRAMICUS SMITH, new species}

(Figs. 1, 2, 3,)

\section{Worker-Length $4.8 \mathrm{~mm}$.}

Mandible 8-toothed, the largest of the teeth being the first, second, fourth, sixth and last. Compound eye as in the mexicanus group: Large, protuberant, and with many facets, placed very close to the posterior corner of the head, its greatest diameter approximately one and one-half times the length of the first funicular segment. Ocelii extremely small. In profile, the pronotum and much of the mesonotum rather evenly and strongly convex, the posterior fourth to the posterior third of the mesonotum distinctly impressed; base of epinotum sharply ascending from meso-epinotal suture to meet the flat, declivous surface of the epinotum in a rather broad, bluntly rounded angle or "pyramid-like" structure; declivous surface approximately twice the length of the basal surface. In profile, the petiole high (higher than the epinotal spiracle), with a weakly convex anterior surface and a flat posterior surface, the two surfaces meeting above to form a strongly compressed (anteroposteriorly), sharp superior border; viewed posteriorly the petiole with dorsally converging sides and the superior border with a distinct emargination.

Dorsal and anterior surface of head and mandibles bearing a number of long, erect hairs, those on the anterior border of the clypeus unusually long. Lower surface of head with ammochaetae and 
lower surface of mandible with long hairs. Thorax almost destitute of erect hairs except for a small number (usually about six) on the pronotum and a smaller number on the mesonotum. Petiole also practically devoid of hairs, occasionally an erect hair or two on the superior border. Coxa with erect hairs; erect hairs also on the flexor surfaces of the femur, tibia and tarsus. Posterior border of each of the gastric segments with a row of hairs; also a number of short, sparse, erect hairs elsewhere on the gastric segments; apex and ventral surface of gaster with longer and more numerous hairs. $\mathrm{Pu}$ bescence sparse, fine, closely appressed, not obscuring the ground surface, thickest and most apparent of the gaster.

Body usually subopaque in general appearance, but in some lights certain parts are shining, this being especially true of the dorsal surface of the head. Color a sordid light or yellowish brown with the thorax and antennae lighter than the head and gaster.

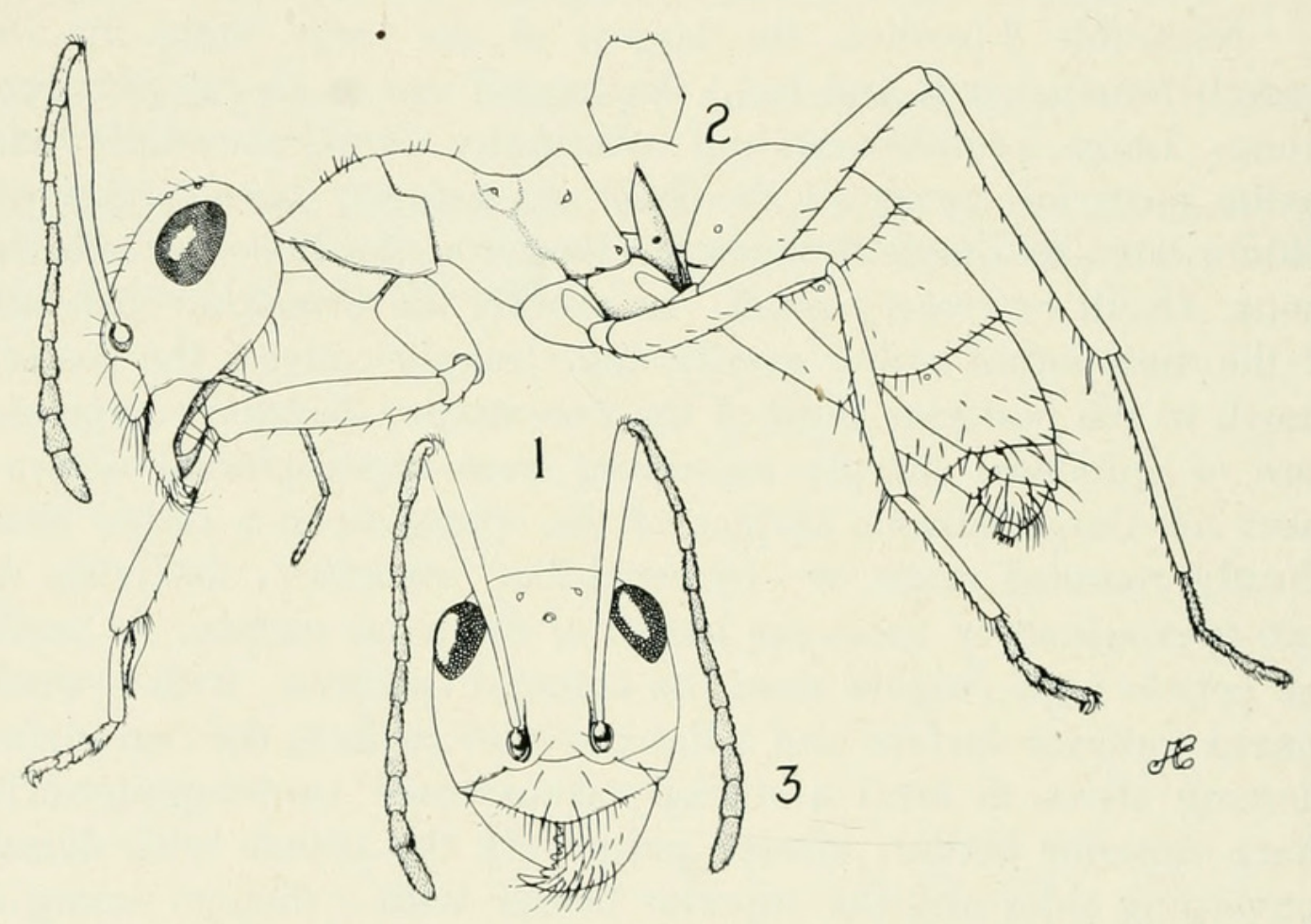

(Figs. 1, 2, 3)

Myrmecocystus pyramicus, new species. Fig. 1. Profile of worker. Fig. 2. Posterior view of petiole. Fig. 3. Anterior view of head. (Illustrations by Miss Addie Egbert.) 
Type Locality: Nevada Dominion Mine, Pymarid Mining District, five miles west of Mullen Gap (Pyramid Lake), north end of Pah Rah Mountains (Nevada Highway 33), Washoe County, Nevada. The ants were collected by Ira La Rivers on April 7, 1951, from a colony in a small, open mound nest in a sand clearing of Artemisia tridentata, where the females and males were beginning to swarm near sundown.

Described from a holotype and 37 paratype workers. The holotype and 25 paratype workers have been placed in the collection of the United States National Museum under U. S. N. M. No. 61265. The remaining paratypes are in the collection of Dr. La Rivers. The five male and ten females have not been described as they do not offer good characters for recognition.

The paratypes vary especially in size, pilosity, and extent of the development of the "pyramid-like" structure of the epinotum. The range in size of this form cannot yet be positively stated on the basis of the few specimens examined. It is thought, however, to approach that of navajo Whlr., the major worker of which is almost $5 \mathrm{~mm}$. in length. The range in length of my pyramicus series is approximately 3 to $5 \mathrm{~mm}$. The pilosity of the thorax and petiole may vary from almost no erect hairs to a few as stated in the above description.

This new form belongs to the mexicanus complex as evidenced by the large eyes and their placement, by the small ocelli, and by the light to yellowish brown color of the body. In Creighton's 1950 publication, Ants of North America (Harvard Univ., Mus. Comp. Zool. Bul. 104:441) this ant keys to couplet four which includes navajo and mojave. Specimens have been carefully compared with cotypes of both these forms. From navajo, to which it is apparently most closely related, pyramicus can be distinguished by the dentition of the mandibles, pilosity of the body, and the shape of the epinotum and petiole. $M$. pyramicus has eight instead of nine teeth on the mandibles, and a pyramidshaped instead of a convex epinotum. The scape is free of erect hairs and the thorax and petiole are also either free of erect hairs or only have a very few, whereas in navajo there are numerous erect hairs on both the scape and thorax. The petiole of pyramicus is strongly compressed anteroposteriorly and the superior border is sharp and usually has a distinct emargination. Navajo has a rather thick petiole (anteroposteriorly) and the superior border is thick and blunt. M. pyramicus seems to be one of the most easily recognized forms of this genus in North America. 
The shape of the epinotum readily distinguishes it from any other form, but to supplement this there are other good characters, such as color, pilosity, dentition of the mandibles, size and placement of the eyes, and shape of the petiole.

Apparently pyramicus is a nocturnal ant which lives in very arid regions. Its food is most likely honeydew and the flesh of small arthropods. No repletes are yet known.

\section{VEROMESSOR LARIVERSI SMITH, new species}

\section{WORKER-Length $5 \mathrm{~mm}$.}

Head, exclusive of the mandibles, subrectangular, with a weakly convex, almost straight posterior border. Antenna 12-segmented; scape slender, curved at base, enlarged apically, the apex clearly surpassing the posterior border of the head; base of the scape lacking a lobe or other enlargement as in some species of Veromessor; funiculus enlarged apically but not forming a clearly-defined club. Eye large, convex, strongly protuberant, placed approximately its greatest diameter from the base of the mandible, without the sharp anteroventral angle of pergandei. Clypeus convex, lacking the median tooth on the anterior border as in pergandei. Mandible large, subtriangular, with two large apical and five or six somewhat less distinct teeth. Thorax, in profile, with a strongly convex promesonotum. Approximately the posterior half of the mesonotum with a distinct impression which is clearly longer than deep. Meso-epinotal constriction well defined. Epinotal spine subtriangular, short, acutely pointed, much less than half the length of the basal surface of the epinotum. Legs rather long and slender, without noticeably incrassated femora and tibiae. The distinctly concave anterior surface of the petiolar node meeting the posterior surface of the node in a bluntly rounded angle; antero-ventral surface of the petiole with a very poorly defined, vestigial tooth. Petiole viewed anteriorly somewhat violin-shaped. Postpetiole, from above, subcampanulate, broadest posteriorly. Gaster, viewed dorsally, oval, without apparent humeral angles.

Frontal region of head with fine, longitudinal striae or rugulae. Cheeks with coarse, longitudinal rugulae, those around the antennal foveae more or less concentric. Remainder of head with an obscure, delicate shagreening. Punctures on head sparser and less visible than in pergandei. Pronotum with transverse rugulae in addition to the shagreening. Mesopleuron and side of epinotum rugulose- 
punctate. Petiole and postpetiole delicately shagreened.

Ventral surface of each side of head and also ventral side of each mandible with remarkably long ammochaetae as in pergandei. Anterior border of clypeus with a row of long, curved hairs. Dorsal surface of body with rather numerous, erect, yellowish hairs of variable length, many of these unusually long. Hairs on antennal scape short, somewhat appressed.

Head, thorax, petiole and postpetiole brown, gaster darker; eyes and mandibular teeth black.

Type locality: Nevada Dominion Mine, Pyramid Mining District, Mullen Gap (five miles west of Pyramid Lake), Washoe County, Nevada, May 8, 1951, nesting in sand, Ira La Rivers.

Described from a holotype and 38 paratype workers. The holo-

type and 25 paratypes have been placed in the collection of the United States National Museum under U. S. N. M. No. 65266. The remaining paratypes have been returned to Dr. La Rivers.

Paratypes vary in size and color. The range in length is from 3.8 to $5.2 \mathrm{~mm}$. The color of some specimens, especially of the smallest workers (which may be callows), is light brown. A small infuscated spot is present on the vertex of some individuals and absent on the vertex of others.

This new form has been carefully compared with types of all other North American Veromessor. In the Wheeler and Creighton key to Veromessor (1934, Proc. Amer. Acad. Arts and Sci. 69:361) it keys to couplet three and in Creighton's North American Ants (l.c., page 158) it keys to couplet two. In each case the couplet includes the same forms, pergandei and stoddardi. V. lariversi is more closely related to pergande $i$ than to any other of our Veromessor. It differs especially from that species in the more convex and protuberant eye (which lacks the distinct antero-ventral angle of pergandei), the absence of a tooth-like process on the middle of the anterior border of the clypeus, the longer and more slender antennal scape (the scape of pergandei fails to attain the posterior border of the head in some individuals and does not surpass it in others), the coarser sculpture, different color (piceous brown to jet black in pergandei and the longer and more slender, subcampanulate postpetiole.

Although little is known about the biology of lariversi it is assumed that because of close resemblance of the species to pergandei, 
this new form will also be found capable of living in very arid areas of high temperature. No doubt, it too feeds largely on seeds. Besides lariversi, andrei (Mayr) is the only other Veromessor that has been reported from Nevada. 


\section{$2 \mathrm{BHL}$ Biodiversity Heritage Library}

Smith, Marion R. 1951. "Two new ants from western Nevada (Hymenoptera, Formicidae)." The Great Basin naturalist 11, 91-96.

https://doi.org/10.5962/bhl.part.22420.

View This Item Online: $\underline{\text { https://www.biodiversitylibrary.org/item/33385 }}$

DOI: https://doi.org/10.5962/bhl.part.22420

Permalink: https://www.biodiversitylibrary.org/partpdf/22420

\section{Holding Institution}

Harvard University, Museum of Comparative Zoology, Ernst Mayr Library

\section{Sponsored by}

Harvard University, Museum of Comparative Zoology, Ernst Mayr Library

\section{Copyright \& Reuse}

Copyright Status: In copyright. Digitized with the permission of the rights holder.

License: http://creativecommons.org/licenses/by-nc-sa/3.0/

Rights: https://biodiversitylibrary.org/permissions

This document was created from content at the Biodiversity Heritage Library, the world's largest open access digital library for biodiversity literature and archives. Visit BHL at https://www.biodiversitylibrary.org. 